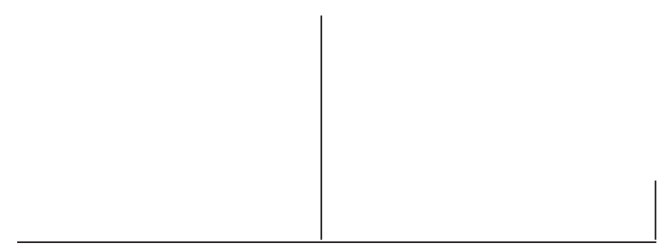

Rev. Latinoam. Psicopat. Fund., IV, 3, 89-115

\title{
Cybelle: o tratamento de uma adolescente anoréxica*
}

\author{
Anna Victoi
}

\begin{abstract}
$O$ autor apresenta uma reflexão sobre o quadro de cura de uma adolescente anoréxica. A partir do material clínico, são desenvolvidas algumas questões sobre a transferência $e$ contratransferência. $O$ autor adianta implicitamente uma hipótese de que a transferência primária (sensorial) ocupa um lugar importante, a saber, primordial na cura dos adolescentes em dificuldade. Assim explorando esta hipótese e demonstrando na clínica uma evolução na direção de uma transferência mais secundária e de uma construção do pensamento simbólico adolescente.
\end{abstract}

Palavras-chave: Psicanálise, transferência, contratransferência, adolescentes, clínica

* Texto originalmente publicado em Cure em adolescence, obra coletiva dirigida para $\mathrm{Ph}$. Gutton, Paris: L’Harmattan. Tradução de Monica Seincman, revisado pela autora. 


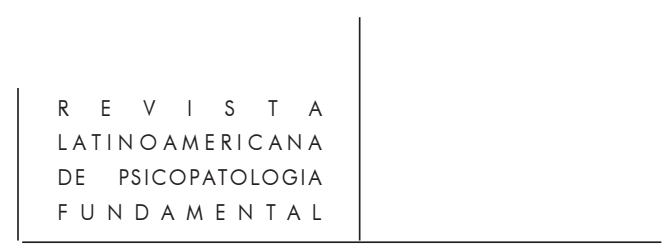

A adolescência foi longamente teorizada como um período de crise, de mudança. Ela é vista, seja pelos pais, seja pelos psicanalistas, seja pelos próprios adolescentes, como uma etapa importante, até mesmo difícil. "Se é o período mais belo da vida, quero a feiúra dos adultos", diz um adolescente.

$\mathrm{O}$ adolescente chega à consulta com suas próprias palavras, bem características deste período: "Não estou bem, não consigo mais estudar, tenho o ódio em mim, tudo me ocupa a cabeça, não tenho amigo ou amiga, não sei mais quem sou, duvido de tudo, sinto-me perseguido pelo olhar dos outros, não posso mais pegar o trem, o elevador, segunda-feira quando me levanto, penso na sexta, está tão longe que não posso mais sair de casa".

Escutamos aí os motivos de uma consulta, que traduzem um sofrimento, um “desconforto em viver". Nestas palavras, percebemos uma demanda às vezes passiva. "Se a senhora acha que preciso de ajuda, posso tentar" ou, ao contrário, repleta de lágrimas, no seio de um desamparo e de uma hemorragia pulsional, a demanda pode ser explicitada pelo sofrimento, ou então formulada por meio da ambivalência. "Não preciso ser ajudado, mas venho". A demanda assim moldada já é uma das características bem particulares do tratamento dos adolescentes.

Desta maneira, o tratamento de adolescente é "particular" em virtude de resultar da "singularidade" de sua problemática. O que E. Kestemberg desenvolveu em seus trabalhos: a adolescência é um verdadeiro desafio, não é um bom período para se fazer uma análise. Podemos acreditar nesta hipótese, se tivermos como modelo o tratamento-tipo do adulto. 


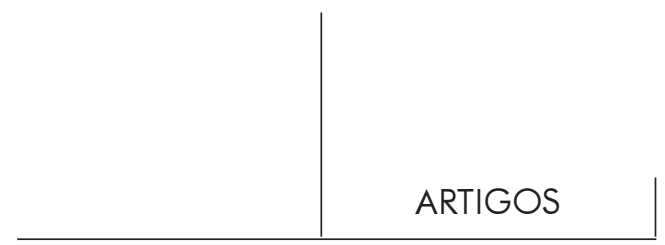

A moldura ${ }^{1}$ interna do tratamento

A psicoterapia da adolescência, com suas particularidades, é dificilmente praticável sem uma moldura interna e uma moldura externa do tratamento. A moldura interna do tratamento engloba, por primeiro eixo, o conjunto teórico de nossa formulação do desenvolvimento psíquico da adolescência e os elementos da contratransferência relativa ao adolescente em questão. O suporte teórico de nossa moldura encontra-se na psicanálise, na qual o texto de referência é a teoria formulada por S. Freud (1905) sobre a puberdade, a ele sendo acrescentados os trabalhos psicanalíticos de hoje sobre a adolescência, tais como os de P. Gutton sobre a teorização da "novidade pubertária". A pluralidade das teorias psicanalíticas fornece os apoios necessários para a elaboração de um conceito personalizado sobre o processo da adolescência.

O segundo eixo da moldura interna é a construção de uma teoria relativa ao adolescente que está diante de nós. Encontramos os elementos a serviço desta individualização conceitual nas primeiras impressões contratransferenciais e transferenciais, como por exemplo, em um detalhe particular observado no primeiro contato capaz de ter um sentido para nós. Estes elementos dão-nos a capacidade de fantasiar, representar e criar uma idéia do sujeito que está diante de nós. Estes dois eixos da teorização sobre o processo de adolescência e sobre o adolescente levamnos à elaboração de um projeto de tratamento.

O elemento fundamental do projeto é dar lugar ao pensamento, à figuração, representação e simbolização do adolescente. De um ponto de vista econômico, é definido como a construção de uma capacidade de secundarização do pensamento e da relação com o objeto.

O terceiro eixo de nosso projeto de tratamento é o estabelecimento dos laços, em uma continuidade narcísica pelo viés da relação transferencial. Esta tempera a estima do Eu e permite ao adolescente manifestar sua vida pulsional em torno das zonas exógenas e sua maneira de entrar em relação com o objeto. O projeto de tratamento implica uma teorização do espaço e do tempo terapêuticos.

\section{O espaço terapêutico}

O espaço terapêutico é a zona intermediária (transicional) entre a moldura interna e a moldura externa do tratamento. Este conceito de espaço transicional é formulado por D. W. Winnicott (objeto transicional), em seguida utilizado por diversos autores

1. Cadre de tratamento - Moldura do tratamento: elementos teóricos e pessoais que o psicoterapeuta utiliza na construção do espaço terapêutico para acolher o sujeito em atividade de composição do seu quadro clínico. 


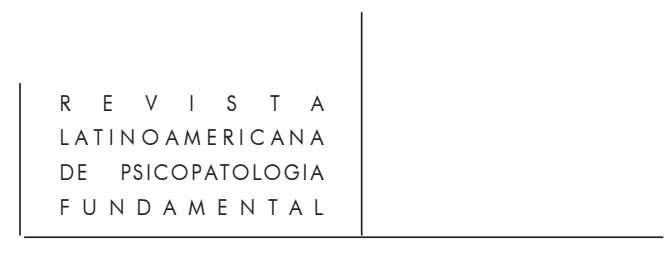

a partir de 1980, tais como E. Kestemberg, P. Jeammet e outros. O conceito hoje faz parte de uma referência da moldura de acompanhamento do adolescente, tanto individual quanto institucional.

A primeira idéia que nos inspira este espaço do tratamento ou espaço da transferência e contratransferência é a elaboração de uma distância psíquica que separa o adolescente de seus pais, facilitando assim a idealização e a desidealização, a ressexualização e a dessexualização do objeto no espaço psíquico do adolescente estendido no espaço terapêutico.

Um outro elemento do espaço terapêutico é seu caráter de apoio e de laço, de "escoramento e ligação" a transferência traz um sentido à relação com o objeto. O objeto da transferência é um organizador com seu papel de apoio perdido no momento pubertário. Esta posição delicada de esteio implica uma clareza sobre o tipo de nossas intervenções principalmente as que estão ligadas à transferência.

$\mathrm{Se}$, no início, formulamos uma teoria personalizada do adolescente, encontramonos face ao sistema defensivo do paciente. Então, ficamos atentos para não demolir um sistema psíquico já fragilizado por um processo patológico. Por exemplo, a interpretação do amor na transferência parece-nos intrusiva para um sistema psíquico que elabora suas defesas contra a intrusão e a perda do objeto.

Um outro exemplo: se o sistema defensivo organiza-se no sentido do controle do tempo, afetos e objeto da transferência, não intervimos para quebrar este processo, mas estamos presentes, com o objetivo de estabelecer uma continuidade do movimento psíquico no espaço transferencial.

Podemos resumir esta exposição da moldura terapêutica (para nosso paciente) na elaboração de um espaço em que o processo da adolescência possa edificar-se ou ter prosseguimento: falamos de um espaço de tratamento adolescente em um tempo flutuante. Nesta construção a dois, pensamos reconstituição da representação ou na aproximação das imagos parentais edípicas.

\section{A moldura externa do tratamento}

Entendemos por isto o espaço externo do tratamento e as estratégias de acolhimento do adolescente. $\mathrm{O}$ ideal é receber o adolescente sozinho em tratamento. Mas esta situação é, às vezes, impossível: os pais acompanham o adolescente em sua primeira entrevista. Nossa regra de recepção dos adolescentes é jamais receber os pais sem a presença do adolescente, regra anunciada no momento em que o encontro é marcado pelo telefone. Também anunciamos que a presença do casal parental é desejável (no caso de pais divorciados, recebemos o adolescente com cada genitor separadamente).

Durante a primeira entrevista, no caso de sentirmos nos pais a impossibilidade de se afastar da terapia do adolescente, propomos, ao longo do tratamento, entrevistas 


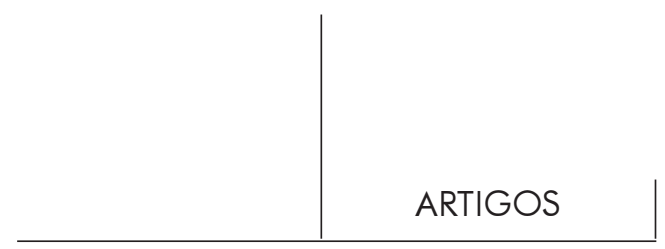

com o adolescente e os pais. A freqüência de tais entrevistas está, certamente, ligada ao grau de culpa dos pais em relação ao sintoma apresentado pelo adolescente. Um dos objetos destes encontros é a elaboração do lugar da terapia do adolescente, como um espaço próprio ao sujeito, dando base a um processo de separação e individuação. Não sendo nosso objetivo teorizar o lugar dos pais na psicoterapia dos adolescentes deter-nos-emos nesta breve observação.

Podemos enunciar agora o objeto de nosso trabalho: os pais ou as imagos parentais. Em outras palavras, ter sob nossos olhos os pais do sujeito ou trabalhar com as imagos do meio familiar fornecida pelo adolescente. De acordo com nossa moldura, ficamos com as imagos parentais. A presença do inconsciente no tratamento é suficiente para nos engajar na construção de uma psicoterapia sem ter "a história do adolescente" contada pelos pais. No entanto, é importante dar um lugar às protofantasias e à cena pubertária ${ }^{2}$ sendo assim, a construção da história do adolescente se dá por meio do simbólico em ligação com a transferência.

\section{As entrevistas preliminares}

Fazemos entrevistas preliminares antes de elaborar com o adolescente as modalidades do tratamento. S. Freud (1904) expõe em "A técnica psicanalítica" as regras que se aplicam ao início do tratamento: ele as nomeia entrevistas de "sondagem", o que permite melhor conhecer o paciente. Com isso, entendemos não apenas o conhecimento de seu funcionamento psíquico, mas, ainda, o de seu modo de entrada em relação "pré"-contratransferencial e "pré"-transferencial.

Durante estas entrevistas preliminares, que são bastante breves, nossa escuta do adolescente é pontuada de intervenções, destinadas a relançar o discurso. Não praticamos entrevistas de avaliação, como muitos clínicos da adolescência.

Um outro ponto importante de nosso procedimento de recepção e a pouca importância que damos aos dados de anamnese. A investigação exaustiva de tais dados parece-nos inútil e no tratamento do adolescente, o "demais-dito" durante estas entrevistas é um elemento que bloqueia e engana o processo do tratamento, não somente para o próprio adolescente, mas para o terapeuta, na elaboração de suas "Idéias" sobre o adolescente em demanda. Pensamos que os dados que fazem o objeto de uma investigação durante as entrevistas preliminares barram a construção da história própria ao adolescente no desenvolver do processo terapêutico. 


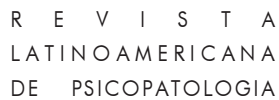

\section{O contrato da transferência e contratransferência}

Sucedendo às entrevistas preliminares, estabelecemos com o adolescente um contrato de tratamento. Este contrato de tratamento tem como base nossas impressões durante as entrevistas preliminares ou durante o primeiro contato com o adolescente (e seus pais, se for o caso). Este contrato de tratamento é elaborado com adolescente, compondo com as regras da recepção. Em outras palavras, o contrato com o adolescente e seus pais (se for o caso) é adaptado ao tipo de "pré"transferência esboçada pelo sujeito e à nossa vivência "pré"-contratransferencial ocorrida durante as entrevistas preliminares.

A idéia da palavra "contrato" é extraída de nosso quadro teórico, ou seja, a constelação edípica que compõe um dos organizadores psíquicos universais, e tudo o que isto implica para o adolescente. S. Freud (1912) evidencia o primeiro contrato em "Totem e tabu".

A primeira forma de organização elabora-se com a renúncia às pulsões, o reconhecimento de obrigações mútuas, o estabelecimento de certas instituições declaradas invioláveis (sagradas). Esta idéia de "contrato" implica a construção ou a uma aproximação das imagos parentais edípicas na relação a dois.

Assim, elaboramos com o adolescente, no decorrer da última entrevista preliminar, as modalidades do contrato terapêutico. Seu conteúdo engloba o ritmo das sessões, a periodicidade do encontro com os pais e o adolescente (se os pais são incapazes de se separar do adolescente), o limite de nossas ações sobre as intervenções no exterior do tratamento.

\section{Introdução ao caso}

Após este breve resumo da teoria de nossa prática, vamos relatar a psicoterapia de uma adolescente de dezessete anos. A psicoterapia acabada, esboçamos alguns escritos sobre este tratamento que durou três anos. O relato do caso (no grupo de trabalho dirigido por P. Gutton) assinalou a questão da nossa neutralidade. Durante este tratamento, nossas intervenções não comportavam a neutralidade presente no tratamento clássico de um sujeito portador de um Ego bem estruturado.

Alguns colegas levantaram a questão da impossibilidade "de uma neutralidade" e mesmo sua inexistência, da incapacidade humana de ser neutro na situação de uma sessão de psicanálise. Sem aprofundar tal discussão, podemos afirmar que, para esta adolescente, a neutralidade do terapeuta tinha uma outra tradução.

M. Laufer (1984) é um dos psicanalistas da adolescência que define a dificuldade desta "neutralidade do analista" ante certos adolescentes que apresentam uma ruptura do desenvolvimento. Segundo M. Laufer, esta ruptura expressada, por exemplo, pela anorexia significa que o adolescente renunciou para sempre a toda esperança de 


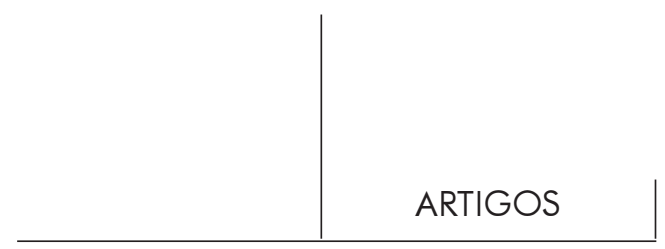

restaurar a relação com o genitor edípico, que renunciou a sentir que sua vida passada e sua vida presente podem estar de alguma maneira sob sua responsabilidade. $\mathrm{M}$. Laufer continua: se o adolescente aceitou empreender um tratamento, é porque ele deu ao analista a possibilidade de questionar suas soluções precedentes. "A neutralidade do analista", deste ponto de vista, é uma posição insustentável e M. Laufer diz que esta neutralidade é não apenas contrária ao seu empreendimento, mas também às tentativas e esperanças inconscientes do adolescente. A neutralidade (clássica) equivale, enfim, à confirmação do desespero do adolescente.

O funcionamento psíquico da adolescente que vamos apresentar exigiu intervenções que consistiam em verbalizar atos do adolescente, levando o sujeito a uma posição mais objetal. A neutralidade do terapeuta está presente através do respeito das capacidades de análise do adolescente.

\section{O encontro: a magreza pálida de Cybelle}

Cybelle (eu a nomeei assim) chegou para uma consulta, estava magra, pequena, diáfana, extremamente pálida, translúcida. Minha primeira impressão era de ter diante de mim uma meninota doente, em sofrimento. Ela se sentou na beira de uma poltrona tomando o cuidado de manter sua coluna vertebral verticalmente colocada, dandome a sensação de que não tinha posição, apoio para se postar em lugar algum. Ela sempre se mostrava em suspenso. Com suas mãos avermelhadas, unidas sobre seus joelhos, ela me falava em uma voz baixa e monocórdia.

Cybelle não se implicava, ela vinha se consultar "porque seu médico o queria". Após um longo silêncio, perguntei-lhe por que seu médico queria assim. Entre o silêncio e a hesitação, ela não sabia como falar. Dei-lhe a sugestão de simplesmente falar, eu podia compreendê-la. Finalmente, ela diz ter sido hospitalizada em um serviço de pediatria durante dois meses e meio, havia somente três dias que ela havia deixado o hospital. O motivo de sua hospitalização era uma "perda de peso", e seu médico, diagnosticando uma anorexia, prescreveu uma psicoterapia.

Neste primeiro contato, Cybelle falou muito pouco e, no final do encontro, como perguntei sua idade, sua resposta foi acompanhada por um sorriso infantil com uma dose de triunfo: Cybelle tinha dezessete anos e meio. No final do primeiro encontro, marquei um segundo e um terceiro encontros. O pediatra de Cybelle facilitou bastante minha tarefa. Ao prescrever uma psicoterapia, o médico indicou que ela devia tomar as providências sozinha, sem ser acompanhada pela mãe. Desta forma, combinamos com a adolescente prosseguir com os encontros individuais, sem a presença dos pais. Estávamos no período das entrevistas preliminares. Os dois encontros seguintes reproduzem o modelo relacional do primeiro, ou seja, grandes momentos de silêncio e algumas palavras sobre sua escolaridade. Ela nunca gostou 


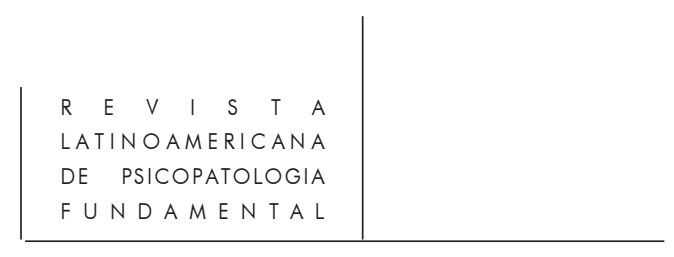

da escola, e interrompeu seus estudos no final da terceira série. ${ }^{3}$ Atrasada e não tendo condição para prestar o $\mathrm{BEP}{ }^{4}$ Cybelle começou uma formação profisssional.

No terceiro encontro, Cybelle fala sobre sua família. Ela era a terceira de uma família com quatro filhos: uma irmã de vinte e cinco anos, um irmão de vinte e um anos, Cybelle (dezessete anos) e uma "irmãzinha" de quatorze. Com uma boa relação com o pai e a mãe, "nada mais tinha a acrescentar". Segundo suas palavras, ela possuía uma família ideal. Uma frase de Cybelle, no final de cada entrevista era, para mim, bastante significativa: "Devo ainda voltar?" Ela ainda não se sentia implicada e não apresentava demanda explícita alguma de psicoterapia.

No final do terceiro encontro, programei o quarto, comunicando-lhe o projeto de falar sobre a prescrição de seu médico: uma psicoterapia. No entanto, com as três entrevistas preliminares, pude elaborar uma idéia sobre o funcionamento psíquico de Cybelle. Meu projeto era, então, bem modesto, não tinha o objetivo de fazer uma investigação ou a anamnese, mas sim de deixar suas primeiras palavras tomarem lugar em minhas idéias, dando, assim, uma continuidade ao relato da adolescente. Encontramos o seguinte procedimento nos escritos de S. Freud (1913) seguidos pelos estudos de E. Kestemberg sobre a adolescência: quaisquer que sejam nossos critérios de avaliação, a anamnese não se constitui um deles, nem os acontecimentos biográficos, mas sim a possibilidade de imaginar refazer juntos uma história que permitirá reencontrar a história do passado.

Evidentemente, as entrevistas preliminares eram em número maior do que de hábito. Eu estava convencida de que esta atitude era motivada por minha primeira impressão. Segundo minhas intuições, Cybelle não podia começar uma psicoterapia precipitadamente, saída de uma hospitalização, correndo o risco de em seguida interromper. Querendo evitar-lhe o fracasso de um trabalho pessoal não acabado, quem sabe até nem começado, fiquei dois meses fazendo entrevistas muito espaçadas.

Um sentimento fazia-se presente em mim, desencadeado pela percepção de seu sofrimento, de seu descomprometimento com a vida e pela representação da morte que embalava seu corpo. Este sentimento me levou a refletir sobre as possibilidades psíquicas que Cybelle tinha de começar e dar continuidade a uma psicoterapia e sobre a moldura de tratamento.

\section{Após o encontro: o contrato da transferência e da contratransferência}

No quarto encontro, a questão da psicoterapia foi abordada. Cybelle não podia falar sobre suas dificuldades com uma outra pessoa que não fosse a mãe, com quem,

3. Equivalente à nossa primeira série do Ensino Médio. (N. da T.)

4. Exame equivalente ao nosso vestibular. (N. da T.) 


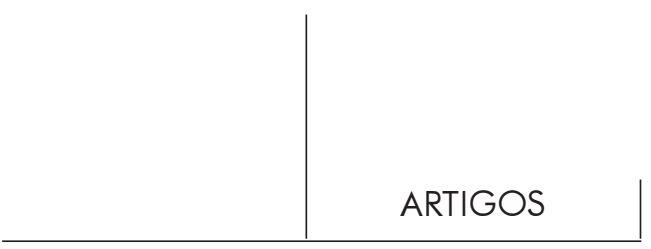

aliás, ela não falava muito. Ela se perguntava como ela ficaria comigo. Eu lhe respondia para "ficar como ela estava". Ela começou a cantar o refrão deste tratamento: "Será que a senhora pode me suportar?" ou "Falar de mim é duro, guardo tudo para mim, jamais digo nada."

Durante este encontro, discutimos sobre a moldura do tratamento. A adolescente estava de acordo em vir duas vezes por semana, ela solicitava insistentemente um encontro meu com sua mãe e que eu também entrasse em contato com seu médico. Lembrava-lhe o que havíamos combinado no final de nosso primeiro encontro; a saber, que a psicoterapia é um processo pessoal. Disse-lhe que não estabeleceria contato com seu médico, uma vez que ele cuidava do peso dela.

Cybelle perguntou-me como eu podia ajudá-la e conhecê-la sem falar com a mãe dela. Respondi-lhe que deixássemos as coisas correrem tais como elas haviam sido prescritas pelo médico. Eu afirmei poder conhecê-la e ajudá-la com o que iria ser dito durante nossas sessões. Ao final desta entrevista, Cybelle entregou-me uma carta da mãe.

Pensei na imagem do "espelho anoréxico" refletindo-se na moldura do tratamento. A mãe de Cybelle escrevia para me pedir um encontro para ela, já que também era anoréxica. Respondi-lhe, por escrito, na presença da adolescente, centrando a carta sobre minha especialização profissional: ocupava-me exclusivamente de adolescentes e seria preferível que ela fosse ver um psicoterapeuta de adultos.

\section{As primeiras sessões: a fome e o frio}

Cybelle mostrava-se vazia, esmaecida e sem vitalidade. Ela falava muito pouco: "O que a senhora quer que eu lhe diga, nada tenho a dizer". Por meio destas palavras, entendia seu desespero, sua falta de arrebatamento com a vida e sua tristeza. Como alguém que nada mais tinha a contar. Com respeito à relação transferencial, a afirmação podia ser encarada também como uma resistência à intrusão do terceiro, provocador de tais sentimentos. Assim, com a mesma postura inicial, ela continuava passiva e fugidia ante minha pessoa, sem me olhar nem dirigir a palavra. Talvez fosse essa uma maneira de travar conhecimento com o outro, de aproximar-se do estranho, de tornar-se familiar com um terceiro. Pensei, então, na criancinha ainda no espelho materno, durante o primeiro encontro com os pais, ela volta as costas para o terapeuta, olhando a parede para se encontrar com o reflexo de sua imagem primária. Cybelle permanecia sob o modo de um contato superficial. Esta incapacidade de entrar em relação com o outro estava marcada pelo medo angustiante de uma implicação afetiva e da intrusão do outro.

Como ela nada podia dizer, ao final dessa quinta sessão, rememorei em voz alta todos os dados enunciados durante as quatro entrevistas anteriores. Durante todo o tratamento, continuei com a mesma fórmula de acolhimento, saudando-a 


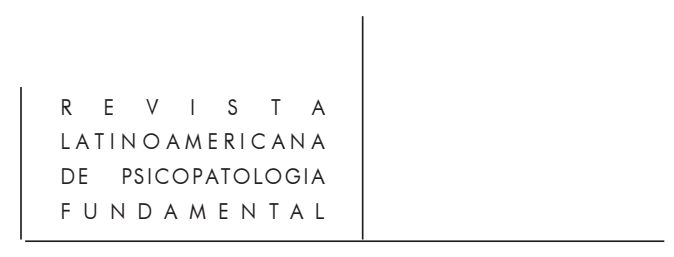

calorosamente no início e, depois, ao final da sessão, dizendo: "Vamos continuar na próxima sessão", com o objetivo de manter o mesmo ritmo durante todas as sessões. As sessões duravam quarenta minutos (às vezes menos), e eu lhe dava uma recepção e uma despedida personalizada (pensando na recepção das crianças no hospital-dia para sua jornada no lugar de vida).

O cumprimento caloroso veio espontaneamente, desencadeado pela minha contratransferência (a terapeuta do bebê identificado mais tarde). Já estávamos na sétima sessão, era inverno e fazia muito frio, mas Cybelle vestia-se sempre da mesma maneira, de preto com uma calça ou uma saia folgada, uma camisa muito leve. Eu sentia frio ao vê-la vestida assim, ao contato com suas mãos frias e com sua insensibilidade em relação ao tempo. Isto me fazia pensar em uma carência de aprendizagem sensorial das necessidades corporais, ou em uma recusa (dénie) de tais necessidades, colocando em segundo plano hipótese de um exibicionismo de sua magreza, ou a sedução por meio de seu corpo esquelético. Algum tempo depois, resolvi intervir. Não mais suportando o frio que dela emanava, e seu estado desesperador (ela vai morrer de fome e frio), tentei dirigir minha intervenção remetendo-a a uma capacidade objetal e lhe perguntei sobre a impressão que eu devia ter vendo-a assim. Ela me respondeu com uma só palavra "Nada". Durante esta sessão, eu the falei sobre as sensações de frio e calor, que a neve provoca o frio o sol, o calor. Comuniquei-lhe a existência dos contos para crianças "evocativos" do tempo. Despertada sua curiosidade, ela me pediu que lhe contasse uma história, já que não conhecia nenhuma ou as havia esquecido. No final de nossa conversa, ela transferiu seus sentimentos sobre o espaço da consulta. Dentro do consultório, a temperatura era agradável ela se sentia bem com o calor da sala. Fiz-lhe observar que, se ela sentia bem-estar com o calor, deveria estar incomodada com o frio. Após um momento de silêncio, ela constatou que nunca prestara atenção no tempo. Eu lhe disse que a vida não era feita de uma única estação.

Cybelle também parecia estar privada de sensações narcissisantes e, durante nossa conversa, tive intenção de lhe fornecer elementos para conduzi-la à descoberta de tais sensações, sabendo a implicação de tais atitudes no manejo da transferência. Como complemento ao trabalho de enriquecimento do Ego, queria lhe oferecer um espaço transicional em que ela pudesse "expressar-se sobre sua fome infinita", não apenas de alimento, mas também de associações, representações e historicidade. Eu estava consciente de minha contratransferência sobre uma menininha. Por enquanto, ela estava no "seio da mãe", um dia talvez ela estará sentada no "colo do pai", e depois poderá andar sozinha e, assim, abordar sua adolescência. Este processo elaborativo somente podia se construir por meio da relação transferencial, por intermédio do apoio e de um reforço narcísico.

Na sessão seguinte, Cybelle chegou mais coberta, mais abrigada contra as intempéries do inverno dizendo nunca ter sentido o frio como na semana anterior ao 


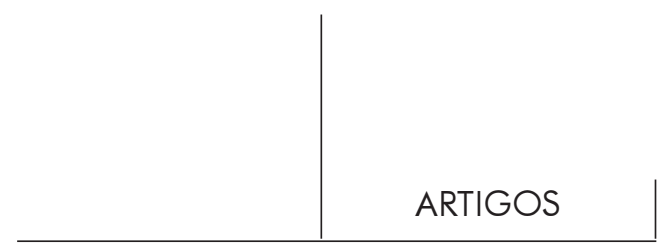

sair do consultório. Cybelle comunicou-me pela primeira vez seus pensamentos. Ela observou (eu penso, disse ela: primeiro sinal de individuação) que sua desatenção "em relação ao exterior" estava ligada a uma única idéia em sua cabeça: "o alimento". "Noite e dia", diz ela, pensava em comida. Sugeri-lhe dividir seus pensamentos, ela me respondeu que guardava tudo para ela e que ela não sabia se eu podia suportála. Após um longo silêncio, Cybelle declarou que eu era "suficientemente forte, robusta", para suportá-la. Na relação transferencial, eu devia encamar o objeto grandioso ou a grandeza do objeto. Eu era para ela um objeto "devendo ser manipulado", com um apego ilimitado. Ela não me deixava mais, seu olhar me seguia, eu sentia seu medo de perder e de se separar, por meio de frases como: "Se a senhora ficar doente, como posso fazer?"; "Se a senhora não me agüentar mais, o que vai ser de mim?" Todas as suas perguntas traziam à luz sua dificuldade de perder ou de abordar a fase depressiva, e estabelecer um vínculo com o outro diferente da fusão com o Objeto Ideal. A entrada na transferência se faz por meio da terapeuta "robusta". Eu recapitulava a trajetória da adolescente (não-verbalizada). Cybelle colocava-se a questão de saber se a terapeuta podia "suportá-la". O tratamento prosseguia seu curso e, neste momento da terapia, ela se instala em uma nova relação com a mãe onipotente, idealizada: a terapeuta era para ela uma "terapeuta robusta". Estávamos em um caso de "suporte". A relação transferencial elabora-se sobre as bases do holding. Evocamos o projeto relativo ao tratamento, a saber, a possibilidade de "refazer juntas" sua história, reencontrando assim a história do passado.

No caso desta adolescente, demos uma atenção especial à moldura do tratamento, ou seja, nossa conduta. O conjunto de nossas atitudes era mais importante do que a interpretação, ou então a moldura do tratamento tomava o lugar da interpretação. Esta importância que demos à moldura é o fruto de minhas impressões durante as entrevistas preliminares. A adolescente não era capaz de seguir um tratamento sob o modelo clássico, incapacidade devida à fraqueza do Ego. Ao dar importância à moldura ou ao conjunto de nossas atitudes (ritmo das sessões, mesma forma de recepção e de final de sessão etc.), uma elaboração de Eu pode se esboçar. É evidente que a transferência edificava-se sobre a dependência primária ao objeto. Assim, o passado da adolescente estava presente na relação transferencial e na elaboração da moldura terapêutica (contratransferência).

Neste momento do tratamento, a única relação de Cybelle com a terapeuta faziase por meio de seus sintomas. Ela verbalizava sobre suas pernas pesadas, sobre as palpitações, as vertigens etc. Durante tais verbalizações eu não fazia comentário algum, já que não possuía o saber médico. Escutando com distância, não solicitava assim explicação ou aprofundamento de um dado sinal.

A terapeuta podia ser uma "terapeuta robusta", mas com um saber limitado. Esta limitação, "ou uma tentativa de desidealização", dava um lugar para a adolescente entrar em relação com um outro "suficiente e imperfeitamente forte". Podemos falar 


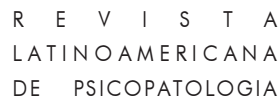

de uma limitação elaborativa do terapeuta, facilitando à adolescente uma rememoração de suas carências primárias na relação da transferência.

\section{O tratamento: um lugar que contém a ânsia de vomitar}

Muito antes da hospitalização, Cybelle não queria mais comer. Seu peso tornavase uma preocupação obsessiva; ela se pesava enquanto selecionava os alimentos. No início, ela sentia fome. No entanto, uma luta atroz contra sua fome iria se desenvolver. Ela não comia praticamente mais nada, uma maçã e um iogurte bastavam. Heroicamente, ela vencera seu desejo de comer. Ou então, sob a forma megalomaníaca (infantil) do "como se", ela vencera sua fome, como Peter Pan. A sensação de fome em seguida a incomodava, mas ela se sentia bem sem comer. Tinha esquecido o alimento, penso que ela recusava a realidade (dénie) de sentir fome. Sendo seu discurso descritivo, ela não podia, entretanto, representar para si ou explicar o que ela chamava de "embriaguez de não mais comer". Eu pensava, sem verbalizar, que nesse momento a sensação de fome tornara-se uma fonte de satisfação intensa, até mesmo de um erotismo primário, e que, em seguida, ela se pusera a recusar (dénier) sua necessidade de sentir sua própria fome e de comer.

Cybelle comunica-nos a história de sua hospitalização. Hospitalizada com vinte e oito quilos, pôde engordar seis quilos em dois meses, depois foi "liberada" por seu médico. Durante a hospitalização, os vômitos haviam começado. Nesse momento do tratamento, uma grande parte do que ela comia era rejeitada por suas "crises de vômitos". Ela sentia uma grande angústia na hora das refeições, transpirando muito e com seu coração batendo muito rápido. Tinha medo de vomitar. Paradoxalmente, os pensamentos durante o ato de se alimentar estavam centrados sobre o ato de vomitar. Ela não provocava seus vômitos manualmente, fazia-o psiquicamente. Se posso resumir minha compreensão de seus sintomas, diria que a sensação de fome era provocada e rejeitada por meio de uma recusa (déni) ou de uma negação (négation) de suas necessidades vitais. Este vai-e-vem auto-erótico traçava um quadro de um masoquismo primário (confirmação da hipótese da (déni) recusa como mecanismo de defesa prioritário).

\section{A relação estabelecida: a analidade}

Cybelle exibe durante as sessões o conteúdo de seus vômitos, em uma descrição detalhada (eu pensava em uma manipulação das palavras) de tudo o que ela comia $\mathrm{e}$, conseqüentemente, vomitava. A oralidade e a analidade presentes, não quero falar de uma fixação, mas de uma oralidade ou analidade que não trazia os traços de uma vida libidinal. Por exemplo, o prazer de devorar o alimento era vivido como uma 


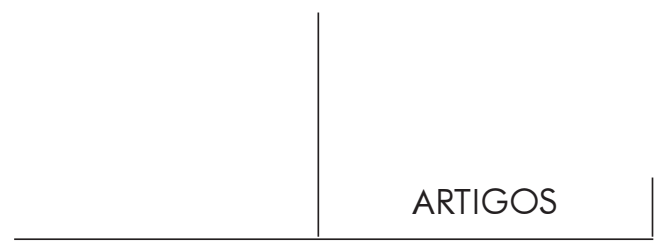

intrusão na integridade corporal, relacionada à transferência, da mesma maneira, como vimos, que o terceiro era vivido como uma intrusão no Ego.

Evoquei seu masoquismo primário, como uma conseqüência de um desligamento entre as funções alimentares e a vida libidinal, com uma carência do desejo e do prazer.

Desde que deixara o colégio, ela se voltou para uma formação em uma PME que fazia a criação de galinhas. Esta escolha foi motivada pela desvalorização de si: "não poderia fazer nada diferente disto", "fracassara na escola" e "não tinha capacidade intelectual" (a autodesvalorização acompanhava cada palavra sobre si). Cybelle trabalhava no abatedouro, esvaziando e limpando as galinhas para embalamento. Muito próxima de um erotismo anal primário, Cybelle trazia-me os "odores fortes" do seu trabalho e o conteúdo de seus vômitos. Ela não ficava incomodada, manipulava os intestinos das aves com prazer, o trabalho agradava-lhe. Uma das raras vezes em que comentei seu trabalho ou seus sintomas, perguntei-lhe sobre a fonte do prazer em seu trabalho. Ela respondeu-me que o prazer que sentia manifestava-se pelo contato de suas mãos com a umidade constante da textura dos intestinos das galinhas.

A atividade profissional estava investida como fonte erótica mostrando esta clivagem do Ego, com o "Id" obscuro e um "Superego" em espelho com o Ideal do Ego. Assim, o trabalho, uma atividade autônoma, era em um primeiro momento fonte de prazer no âmbito do Ego, mas sendo este Ego duplo o trabalho era fonte de prazer auto-erótico para um Ego primitivo.

\section{A transferência pela via do olfato}

Como evocamos, a exibição de Cybelle de um cenário anal ligado a seu trabalho faz-nos pensar a manipulação dos materiais fecais pela criança. Talvez o erotismo anal primário pudesse um dia transformar-se em apreciação sublime de perfumes, quem sabe? Eu falei de erotismo anal primário não sublimado e cheguei a esta conclusão fazendo uma aproximação (não-verbalizada) com os sinais manifestos na relação transferencial. Cybelle procurava os odores fortes de seu corpo, ela coçava a orelha, o couro cabeludo, as axilas e, finalmente, as células mortas de sua pele, para, em seguida, cheirar seu dedo. Eu pensava, assim, no erotismo anal primário na relação como componente psíquico importante. Parecia que o olfato fazia parte da relação transferencial, do amor de si ou do amor de seus próprios odores. Cybelle manifestava o desejo de partilhar os odores de seu corpo com a terapeuta tornando-a assim familiar pela contaminação do olfato. Um outro ponto importante do "cenário exibicionista anal" era a desvalorização do Eu ou a humilhação, como a definiu P. Gutton. Uma vez que esta desvalorização de si está posta na relação transferencial idealizada, ela se torna fonte de construção do Ego. A este respeito, eu lhe perguntei se quando 


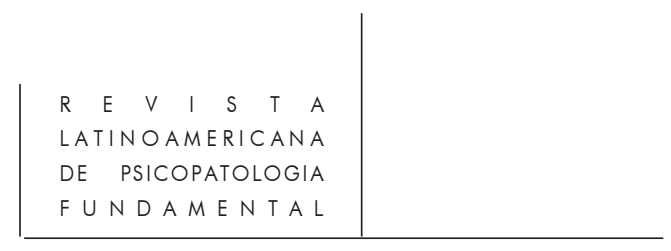

criança ela gostava de brincar com areia. Cybelle começou a falar com precaução da rigidez da mãe: uma vez, não sabia em que idade, ela brincara com terra e água. Sua mãe lhe bateu, depois lavou-a e a vestiu adequadamente. Em seguida, ela ficou sentada durante meio dia.

\section{A erupção contratransferencial}

Cybelle ruminava (ruminação de ordem obsessiva) suas palavras em relação ao alimento: com controle e seleção, ela verificava o conteúdo de seu estômago. Esta analidade também estava presente em nossa relação, ela queria controlar e manipular a moldura do tratamento. Cybelle comunicou-me o fato de enganar o médico: quando ia se pesar, ela bebia dois litros de água. Ganhava, assim, dois quilos, superando o limite do peso exigido (este comportamento era repetitivo, com uma visita médica por semana). Cybelle tinha a certeza de que eu ia telefonar para seu médico para lhe contar tudo.

Lembrei-lhe um aspecto de nosso contrato, eu não me ocupava de seu peso. Cybelle também não suportava uma relação com um objeto que pudesse lhe inspirar confiança, de alguma forma um alimento psíquico. Então, tudo devia estar perdido, jogado "de fora" no exterior, sem deixar traços "de dentro". Como eu havia anteriormente assinalado, não formulei pergunta alguma sobre seu peso ou seus sintomas, eu relançava o discurso, por uma palavra dita ou por uma meia frase. Cybelle se aborrecia profundamente com isso. Expressava seu ódio, verbalizava reprimendas à minha pessoa, eu era um objeto "mau". Ela dizia nunca ter visto uma mulher como eu, ela corria o risco de morrer e eu não telefonava para seu médico, eu a deixava continuar, não a aconselhava com relação à alimentação, não lhe dizia em que deveria pensar quando comia, eu era verdadeiramente uma péssima psicóloga. Respondi-lhe que ela veio me consultar para falar de si e para estar melhor consigo mesma. O refrão do tratamento retomou em voz alta: "É duro falar de mim, guardo tudo para mim". Desta vez, completei: "Você guarda tudo, exceto o necessário para viver, que é o alimento. Você faria melhor, guardando o alimento em sua barriga, e exteriorizando aqui seus pensamentos, você-mesma". A sessão terminou com a fórmula habitual. Como P. Gutton assinala, esta intervenção visava a esclarecer a distinção entre pensamento e corpo-fezes. Em outras palavras, o objetivo desta intervenção era favorecer o desenvolvimento do Ego, enfatizando a existência de um Ego corporal, ao elaborar um distanciamento do ambiente externo, para chegar a uma relação com os objetos internos. 


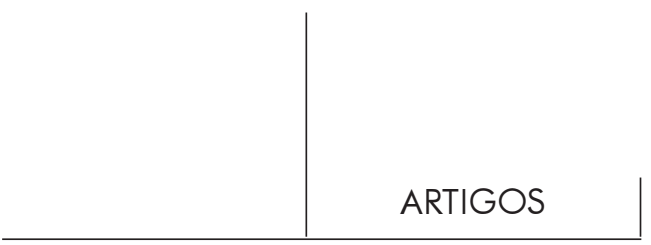

Após a cólera, a experiência da separação

Cybelle pôde expressar, pela primeira vez, sua cólera diante de uma terapeuta que não é perfeita, assim o Ego pode viver as pulsões do "id" e as carências primárias. Mas durante duas semanas, Cybelle faltou às sessões. Em sua volta, propus-lhe que me falasse sobre as duas semanas. Ela me respondeu que lutava contra a falta. Após um longo silêncio, disse-lhe: "Qual falta, a falta de alimento?" Ela me respondeu: "De tudo, falta de alimento, falta de suas sessões, falta da mãe". Cybelle retomou minha última frase - manter seu alimento e exteriorizar os pensamentos - e se pôs a falar dela mesma, dizendo que não vomitava mais, que estava disponível para falar de si. A terapia tomava novos rumos. Cybelle falava de si mais facilmente, aproximandose de seu universo psíquico. Um dado clínico importante depois que ela parou de vomitar e de se privar de alimento é que ela pode estar mais depressiva. A depressão tomava o lugar do sintoma principal, pois, mesmo estando deprimida, ela se revelava um sujeito vivo, contrariamente ao período em que ela ignorava suas necessidades corporais e psíquicas.

Uma dificuldade pessoal que Cybelle pudera descobrir durante estas duas semanas de ausência expressava-se na relação transferencial, a saber, "a transação entre a mãe anal e a mãe edípica". Ela sentia uma grande dificuldade em me aceitar. Eu era diferente de sua mãe e, além disso, ela não podia pensar no fim da terapia ("Isto vai ser muito duro para mim"). Propus-lhe falar dessa diferença (quanto ao fim da terapia, era cedo demais para ser abordado). Cybelle me disse que, se sua mãe estivesse no meu lugar, ela telefonaria para o médico. Cybelle vai enumerar, assim, todas as diferenças entre mim e sua mãe. Havia coisas em mim de que ela gostava e se sentia culpada de vir à sessão com prazer. Achava que consultar uma psicóloga era idêntico às visitas médicas. A culpa na relação de transferência parecia, neste momento, dirigir-se ao objetal.

\section{Após a depressão: a reconstrução}

"Refazer-se"

Vamos fazer uma breve síntese dos elementos mais importantes da história do tratamento de Cybelle, e de algumas intervenções de nossa parte. Uma grande parte de nossas intervenções estava centrada sobre a expressão de seus sentimentos e afetos.

Um exemplo de tal procedimento: Cybelle comunica-me sua dependência em relação à mãe. Desde pequenina, ela não gostava de sair de casa, não gostava da escola. Propus-lhe clarear os sentimentos: ela não gostava de sair de casa ou não gostava de ir à escola. Eu não a deixava na generalidade de seus sentimentos, tentava, tanto quanto possível, levá-la a identificar cada sentimento, personalizar cada afeto, 


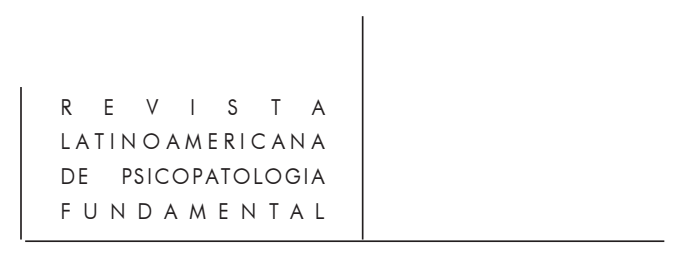

apoiando-os com cada situação. Ela não gostava de sair de casa, para não deixar a mãe. Quando era pequena, não ia com os outros. Não suportava ninguém que não fosse a mãe. Para fazer seus deveres, devia estar ao lado da mãe. Quando esta estava limpando a casa ou cozinhando, Cybelle ficava sempre ao lado dela e, se a mãe saísse, ela caía em pranto. Ela diz ser invadida pela idéia de ficar junto da mãe. Ficando sem sair de casa, ela fazia jogos de salão com sua mãe (à saber quem animava quem). Enfim, ela fazia tudo com sua mãe. Por intermédio das palavras de Cybelle sobre a relação com sua mãe, constatava-se um segundo elemento, a dependência de sua mãe para com ela. Cybelle também cuidava da mãe, ou seja, ela a protegia do aborrecimento e da depressão. Seu papel, em relação à mãe, era o de animadora. Cybelle animava o psiquismo da mãe. Ela era a prótese dos elementos narcísicos ausentes do psiquismo materno, em vez de ter uma troca libidinal, mais objetal, ela era "mãe da mãe".

A adolescente verbalizava seu desespero de não ter nada dela mesma, ela se sentia vazia, vazia como seu estômago na época em que não comia. Eu pensava no vazio como representante de sua dificuldade identitária. Nesta confusão de identidade, entre ela e a mãe, o pensamento e a função alimentar tiveram um mesmo valor, o aparelho psíquico era deslocado para o estômago.

Cybelle falava-me de seu trabalho, a idéia de uma formação nesta empresa viera da mãe: seu pai é açougueiro e sua mãe trabalha neste local há quinze anos. Ela se sentia segura de sair com a mãe todas as manhãs para ir ao trabalho, de estar com a mãe por todo o dia e não ficar sozinha (intervenção sobre os sentimentos em relação ao trabalho). Para Cybelle, era difícil compreender, pois antes de ir trabalhar, ela vomitava escondida de sua mãe e, em seguida, experimentava prazer quando trabalhava, depois, finalmente, uma imensa tristeza ao chegar em casa.

Esta tristeza era compensada por uma hiperatividade, que podia ser vista como uma maneira também de controlar seu cansaço, ou um desconhecimento de tal lassidão. Como não saía de casa, não podia praticar esportes, fazia então a limpeza e passava as roupas, que funcionava como suplemento de seu trabalho. Em um processo de abundância identificatória, identificação com a mãe da mãe, ela limpava quatro casas (irmã, tia e avô). Em uma das sessões, chegou dizendo que tinha dor nas costas, por passar roupa até às duas horas da manhã. Respondi-lhe que jamais pensara que ela pudesse sentir dor onde quer que fosse com toda a carga de trabalho que se impunha. Algumas semanas depois, ela foi capaz de analisar sua sobrecarga de trabalho. O hiperinvestimento nos trabalhos domésticos tinha também um valor de reasseguramento narcísico em relação à sua preocupação "de ser uma boa filha para a mãe", boa, perfeita e normal, eliminando assim seu sentimento de inutilidade e incapacidade (frente aos estudos e às relações sociais).

Em uma destas sessões, ela me diz que a véspera era seu dia de repouso. Manifestei minha curiosidade em conhecer seu plano de trabalho. Cybelle encontrava- 


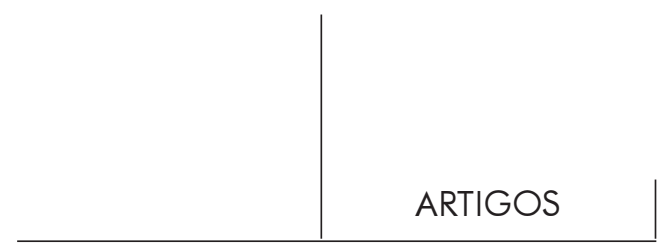

se impossibilitada de saber quais eram seus dias de trabalho. Após algumas tentativas para elaborar, pois misturava o da mãe com o seu próprio, achando estranho não poder enumerar os dias em que ia trabalhar sozinha, intervenho dizendo que entendia uma "confusão". Cybelle, surpresa com minhas palavras, diz que havia uma confusão com sua mãe não apenas no trabalho, mas em tudo. Como fazer para ser ela mesma? perguntou-me Cybelle.

\section{O espelho quebrado: os traços da adolescência}

Quando Cybelle falava de sua depressão, ela dizia que sua mãe dava-lhe seus próprios medicamentos, pois também ela era depressiva (e, eu acrescento, anoréxica). Cybelle estava diante do espelho anoréxico. Aconselhei-a a falar com seu médico e assumir sua depressão que, certamente, era diferente da de sua mãe. Algumas sessões mais tarde, Cybelle falou-me de seu medicamento, um antidepressivo prescrito pelo médico.

Em duas oportunidades, sua mãe esteve gravemente anoréxica, a primeira quando estava grávida de seu irmão e a segunda quando Cybelle tinha dez anos. Propus-lhe falar de sua anorexia, do período que havia antecedido sua hospitalização. Cybelle ficou silenciosa. Na sessão seguinte, ela retomou minha proposta, dizendo que, para ela, era difícil falar de sexo. Na casa dela, não se falava sobre sexo. Disselhe que aqui, no consultório, falava-se sobre sexo. Cybelle havia conhecido um adolescente de dezoito anos no momento em que interrompeu a escola. Ela estava bastante contente e, como não escondia nada da mãe, disse-lhe que tinha um namorado. Imediatamente, a mãe quis conhecê-lo. Ela simpatizou com o namorado da filha e o convidava com bastante freqüência para ir em casa, a ponto de permitir que o namorado dormisse lá. Cybelle não sabia o que fazer, sentia-se inibida, mas sem opção, teve assim, sua primeira experiência sexual. Ela não tinha lembrança alguma desta experiência. Da mesma forma, não mais se lembrava do fato de não mais comer e como a idéia de emagrecer lhe ocorreu. O namorado ficou na casa dela durante toda a semana, excetuando-se o fim de semana quando seu pai chega em casa. Seu pai era açougueiro e trabalhava em um grande abatedouro. Ele bebia muito.

Cybelle rememora o momento de sua hospitalização. Foi sua mãe e o namorado que a levaram ao hospital. Ela não ousava pensar em seus sentimentos com relação a esta situação. Cybelle chorava, gritava, batia os pés no chão. Está com raiva e em desamparo, como a primeira raiva que tivera durante a sessão (momentos em que ela enganava o seu médico com relação ao peso). Mais tarde pôde abordar seus sentimentos. Hoje, ela estava persuadida de que a mãe tivera uma aventura com seu namorado. Na ocasião, não podia pensar, não comia mais, sua menstruação havia desaparecido e, para ela, era o vazio, eu diria a fusão total, a confusão enlouquecedora 


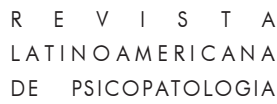

da identidade entre ela e a mãe. Cybelle sentia que não era "mais ninguém", seu desejo era parar tudo.

\section{$O$ ideal sexual moribundo}

Segundo Cybelle, a interrupção havia acontecido por volta dos dezesseis anos. Ela estava também muito próxima de sua irmã mais velha, que, desde cedo, na adolescência, tinha um namorado, com quem se casou aos dezoito anos. Cybelle tinha mais do que sentimentos amistosos em relação a este jovem rapaz, ela estava apaixonada por ele desde pequena. $\mathrm{O}$ marido de sua irmã foi atingido por um tumor no cérebro, e toda a família sabia que ele iria morrer. Cybelle não estava mais na escola, sua irmã a chamou para ir morar na casa dela para ajudá-la a cuidar de seu marido durante a fase final. Era com aflição e lágrimas que Cybelle falava de seu cunhado. Com nostalgia, ela evocava suas lembranças de garota, da época em que ele estava vivo, de sua atenção para com ela, deixando transparecer, assim, um trabalho de luto não realizado. Como dissemos no início de nossa exposição, minha primeira impressão era que Cybelle trazia a morte em si. Ela era a encarnação de seu cunhado agonizante com uma identificação adesiva, ela assumia seu lugar por meio do jogo erótico entre a vida e a morte.

Na história de vida das anoréxicas nada é simples. Em seguida à exteriorização de todos os seus sentimentos relativos à perda, à separação e à boa recordação, Cybelle iria evocar sentimentos muito pessoais, que jamais ousara dizer a alguém, nem mesmo à mãe a quem tudo falava. Ela sabia que devia me falar, e, em seguida que as coisas iriam tornar-se mais "leves para ela", dizia ela. As representações de Cybelle estavam sempre ligadas ao peso, diante de uma terapeuta forte. A adolescente demorou um tempo para me falar disto, com Cybelle o tempo fazia seu trabalho na construção de uma idéia ou de ligação do pensamento. Em seguida, ela podia exteriorizá-la e, mesmo com o desdobramento no tempo de uma idéia, não perdia o fio de seus pensamentos. Eu esperava sempre, já que sabia de sua capacidade de verbalizar. Durante este tempo de espera que podia durar uma semana ou um mês ou mais, falávamos sobre outras coisas. Ela experimentava prazer e curiosidade ao me escutar e ser escutada, ela sorvia minhas palavras, como um tipo de apoio psíquico para se expressar sobre um conflito ou um traumatismo.

Voltemos ao ponto em que Cybelle parou de falar. Ela auxiliava a irmã, cuidando do cunhado. Este rapaz não reconhecia mais ninguém, e não tinha mais qualquer autonomia de vida. Cybelle "limpava" seu corpo e, durante este momento de cuidado, ela iria sentir suas primeiras emoções sexuais (eu pensei na cena pubertária ). Era para a adolescente uma culpa imensa sentir "um prazer em acariciar um homem que estava morrendo". Segundo Cybelle, ela não estava preparada para tocar um homem nu, ela 


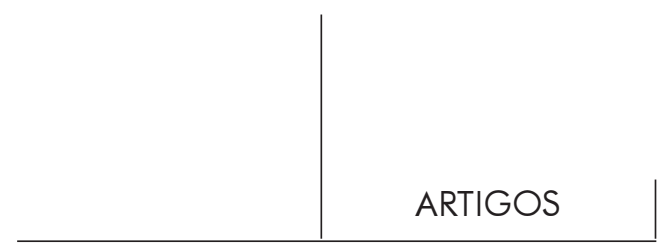

que nunca teve experiência mesmo que relacional com os garotos. Logo após todos estes acontecimentos, ela conheceu seu namorado. Tentou ficar bem com ele, mas isto não funcionou: "Tudo havia parado". E eis a adesão, a solda do Ego Ideal com um Ideal Sexual moribundo.

\section{Cybelle e a castração masculina}

Somente agora, ela sentia que sua vida continuava, tinha amigos, saía de casa e tinha um novo "namorado". Ele tem uma moto, muitos amigos e amigas e, desta vez, ela não o leva para casa, pois é uma relação de fora. Para Cybelle, esta relação é totalmente conveniente. Ela conheceu este adolescente na sala de espera do médico. Ele tem um problema - uma malformação dos testículos -, e deverá fazer várias operações antes de ter relações sexuais, então isto é totalmente conveniente para ela. Ela não se sente pronta para ter relações sexuais, pensa que "deve se fazer antes".

Para Cybelle, era impossível ver um programa na televisão, entender ou ler um artigo que tratasse dos problemas da adolescência, como a droga, a prostituição, o incesto. Ela entrava em pânico, pensando que podia tornar-se uma drogada e uma prostituta. Conforme seus sentimentos, sentia-se uma desconhecida para si mesma. A adolescente tinha a vivência de estar aberta a todas as possibilidades, identificandose (identificação adesiva) com os adolescentes que sofriam, como se ela fosse o outro, o reflexo do outro, revelando a pobreza dos elementos incorporados, não tendo introjetado um modelo identitário.

Hoje, fora de seu isolamento, ela fala muito com seu namorado e amigos, sobre todos os problemas dos adolescentes, "ela sabe quem ela é" e não mais tendo dúvida sobre sua pessoa, ela se sente segura.

\section{Projeto profissional}

Sabemos que uma psicoterapia não é um lugar de elaboração de um projeto profissional, mas, às vezes, este tema torna-se um ponto importante do tratamento. Assim, um dos elementos do tratamento de Cybelle era sua profissão, ela que não mostrava desejo algum de fazer uma formação profissional, querendo somente ficar junto da mãe. No final do tratamento, Cybelle elaborava seu projeto profissional, ela desejava fazer algo ligado à venda de roupas prêt-à-porter feminina. Tal formação foilhe oferecida, e ela devia ir morar em uma outra cidade para seguir seu objetivo. Acabamos nosso percurso e eu recebi notícias suas alguns meses depois. Ela morava em um lar de jovens trabalhadores e continuava também seu "trabalho pessoal". Ela começou uma psicoterapia com um terapeuta, deixando crer, desta vez, em um tratamento mais secundarizado. 


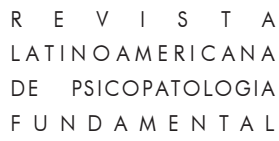

\section{Breves considerações sobre a moldura do tratamento}

O primeiro contato com Cybelle leva-nos a uma adequação da moldura, que é composto de dois terapeutas: um próximo do corpo, garante do contrato de peso e da realidade corporal; o outro psicoterapeuta, distante desta realidade corporal, mas, no entanto, portador de uma outra competência. Podemos falar, na globalidade do tratamento, de uma moldura clivada, revelando assim a clivagem presente no funcionamento psíquico de Cybelle. Em outras palavras, o corpo fazia parte da realidade externa, "de-fora-médico", e o psiquismo fazia parte da realidade interna do tratamento. $\mathrm{O}$ estabelecimento desta moldura clivada foi motivada pelos elementos regressivos observados desde a primeira entrevista. A moldura (de-fora-médico e dedentro-terapia) fazia-nos pensar na dialética do brincar e da realidade. Assim, podemos fazer uma aproximação entre o "brincar e a realidade", em que os dois espaços englobam a realidade psíquica, podemos dizer que o brincar era a moldura interna do tratamento, o "de-dentro", e a realidade era o "de-fora", a realidade corporal. Dentro do possível, tive de me limitar à realidade interna, com o objetivo de uma abertura para uma relação transferencial menos persecutória ou menos intrusiva.

\section{A moldura do tratamento e a traição}

O tratamento toma uma direção mais "adolescente" ou mais secundarizada, no momento em que Cybelle entra em uma nova relação transferencial, a raiva. Ela não concordava comigo quando eu me recusava entrar em contato com seu médico no período em que ela trapaceava com seu peso, bebendo água. Por um lado, era uma trapaça, mas de um erotismo uretral muito infantil; por outro, era uma maneira também de colocar à prova a confiança e controlar uma vez mais suas relações por intermédio da função alimentar e também um motivo de romper a terapia pela traição da terapeuta. Ela tinha motivos para ter tais sentimentos na relação transferencial (soubemos mais tarde). Eu digo que a terapia secundariza-se, em virtude de sua oposição na relação transferencial. Cybelle, que nunca deixara transparecer a menor oposição em relação a seus pais, irmãos ou irmãs, opunha-se verbalmente e em ato a mim. Em meus pensamentos, isto já era uma autonomia, uma existência, uma maneira de ser, um sinal da confiança em si. Então, eu podia "acrescentar" por meio de minhas intervenções "a iniciação à descoberta de seus sentimentos": "Seus sentimentos, quais são seus sentimentos?", ajudando-a e apoiando sua capacidade de sentir.

\section{As intervenções}

Explicitamos anteriormente a importância da reconstrução da história durante o tratamento, o que significa a importância do inconsciente. Assim, minhas 


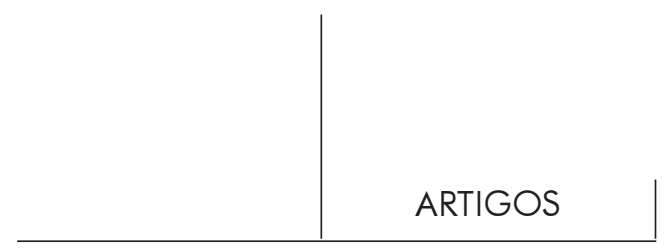

intervenções eram guiadas pelo psiquismo da adolescente. Ela manifestava, durante as entrevistas preliminares, uma forte regressão: minhas intervenções foram elaboradas em relação ao seu funcionamento psíquico.

Minhas atitudes durante o tratamento consistiam em: reunir os dados, rememorar sua história, completar um pensamento, fornecer uma representação. Eu tinha como referência, para tal procedimento, minhas idéias sobre o funcionamento psíquico da adolescente. Sua fragilidade psíquica era uma de minhas preocupações. Eu não podia manter uma atitude centrada na neutralidade de uma escuta silenciosa, como é a prática com os adolescentes "bem neuróticos". Talvez ela se privasse de seu sintoma em virtude das visitas médicas, mas ela não tinha nada além para pôr no lugar. Cybelle iria se confrontar com as "perdas", sem ter a capacidade psíquica de se preencher.

Assim, em um primeiro tempo, o da transferência ao objeto primário, eu assumi o lugar de um terceiro que podia temporariamente reparar um aparelho psíquico sem combustível pensante, coisa que é, para mim, muito freqüente com as crianças (durante um jogo, um desenho, uma história) em quem a inibição ou a pobreza psíquica bloqueia a criatividade de "Ser", a imaginação e a simbolização. Este procedimento consiste em "anexar" um pensamento sobre o pouco que é expresso pela adolescente, favorecendo uma elaboração presente ou propondo elementos que ela pudesse utilizar mais tarde transformando-os. Aqui, certamente, nossas intervenções não comportam a neutralidade de um tratamento-tipo.

Nesta linha de pensamento, durante o tratamento, falamos sobre os mais diversos temas. A troca podia bem ser sobre o cinema, a música, os jardins ou os livros que ela havia lido. Eu integrei no tratamento elementos da vida cotidiana, frutos de nossas conversas, sabendo que, para Cybelle, era importante expressar-se por intermédio dos elementos da realidade, vista a sua dificuldade associativa. De uma banalidade, uma opinião ou um pensamento pessoal elaborava-se.

Uma outra atitude, importante para mim, era minha "ausência" de intervenção sobre seus sintomas. Explicitada anteriormente, esta conduta tinha como objetivo fazer Cybelle descobrir sua própria capacidade de pensar e a autonomia que ela devia ter em relação a seu peso. Nosso "não-saber" tinha como objeto o conhecimento que ela deveria adquirir, o poder dela de dirigir suas necessidades vitais.

Com a relação de confiança estabelecida, comecei a servir-lhe um menu. Este menu era composto de frases bem temperadas como: "Você guarda tudo, menos o necessário para viver, que é o alimento", "A vida não é feita de uma única estação", com o objetivo de dar sabor ao seu alimento psíquico, assim como a representações muito generalizadas. Este menu veiculava uma análise aprofundada ou uma interpretação da situação e, talvez, da gênese dos sintomas, dando significado a um acontecimento, um sentimento ou, como escreveu S. Freud, as "ligações da idéia patogênica a suprimir". As "frases-menu”, acompanhadas pela contratransferência, 


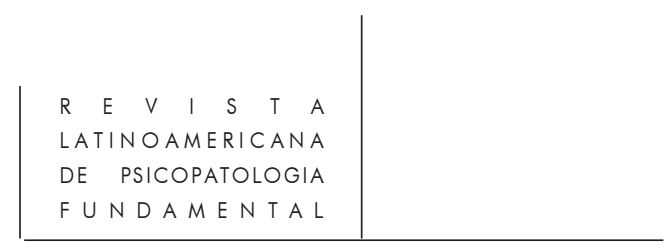

podiam ser utilizadas a seu gosto transferencial: incorporadas, introjetadas, deixadas em um estoque interno para um eventual consumo.

Esta idéia está baseada nos escritos de S. Freud (1904) no qual ele utiliza um conceito de Leonardo da Vinci sobre a diferença entre a pintura e a escultura. Para Leonardo da Vinci, a pintura trabalha per via di porre, colocando sobre uma tela branca "parcelas de cor", a escultura trabalha per via di levare, erigindo no lugar da pedra bruta tudo o que se encontra na superfície da estátua que ela contém (método analítico). No que se refere às intervenções neste momento mais secundarizado do tratamento, ficamos na posição de levare, no entanto as intervenções, durante os momentos primários do tratamento, tinham a expressão de per via di porre.

Cybelle era passiva diante da vida. Ao acrescentar um lugar no tratamento à elaboração de um projeto profissional, ela pôde conceder uma autonomia (de pensamento e de desejo) às atividades necessárias à vida, dentre as quais, a responsabilidade de se alimentar voluntariamente. Este projeto era vital para ela. Não tendo confiança alguma em si, ela se julgava incapaz de ter uma atividade profissional que não fosse limpar as entranhas das galinhas. Ela duvidava de sua capacidade de aprender e de estar com outra pessoa: na transferência, ela duvidava de minha capacidade de suportá-la. Foi assim que dei um espaço no tratamento a seu projeto, como elemento importante do trabalho de narcisação, que era justamente em que o tratamento consistia.

\section{A neutralidade e o respeito}

A posição que mantive durante todo o tratamento era a de respeitar seu limite na análise. Eu podia identificar, por exemplo, as fantasias masoquistas que ela revelava aqui e ali (Ideal sexual moribundo), ou a impossibilidade da adolescente de abordar uma sexualidade genital, ou os componentes psíquicos relativos à homossexualidade primária $^{5}$ (amor ao outro-quase-Eu na transferência), ou uma identidade feminina frágil (o espelho primário anoréxico) e um masculino não elaborado no seio da bissexualidade psíquica decomposta (Cybelle e a castração masculina), ou ainda o pai presente na relação transferencial por sua ausência, ou a negação da rivalidade com suas irmãs e irmão e mãe etc.

Nossa neutralidade era definida pelo respeito às suas capacidades de análise. Nós podíamos pensar em centrar as intervenções, por exemplo, sobre as dificuldades sexuais próprias ao processo da adolescência. Em nosso espírito, se não respeitássemos seus limites, talvez tivéssemos dados muito ricos sobre suas dificuldades de

5. Victoi, A (1999). L'entrée dans la homosexualité primaire. Fou d'amour il hallusine in homosexualité primaire, I. Este conceito foi elaborado como um momento do processo do desenvolvimento homossexual psíquico, à ligação primária com o objeto "não idêntico ao Eu”, um “objeto igual ao Eu". 


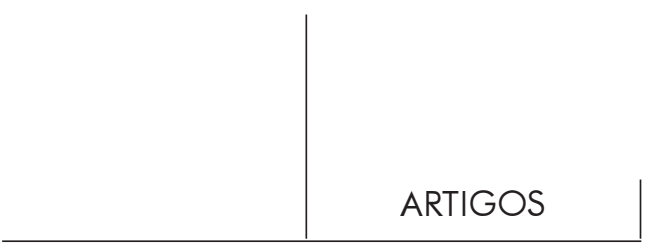

ordem sexual, mas seriam apenas dados, não sustentados por uma possibilidade elaborativa de sua parte. $\mathrm{O}$ tratamento teria se tornado um tratamento sádico.

Eu me explico: sendo sua transferência primária facilitando assim a exploração por indução, deixando a adolescente em uma posição passiva, até mesmo masoquista, esta exploração iria apagar os limites entre o espaço de tratamento e o espaço fora do tratamento, o psicoterapeuta correria, então, o risco de se tornar um "Outro onipotente" que controla e domina a elaboração psíquica do adolescente. O paciente ficará fechado nesta transferência primária, sem possibilidade de aceder a uma transferência mais objetal.

\section{Comentário sobre a transferência e a contratransferência}

\section{Após o encontro: a relação mãe-beb̂e}

Vamos comentar os estágios do desenvolvimento psíquico-sexual na situação da transferência e da contratransferência. Nossa primeira impressão foi que Cybelle se empenhava em uma relação dominada pela oralidade com as trocas em um registro sensorial. Sentimos, desde os primeiros contatos, uma "interrupção do desejo" de se satisfazer. Ela se apresentava como um sujeito amorfo, apático, fraco e sem vontade, traduzindo uma imaturidade pulsional como fonte da inibição. $\mathrm{O}$ encontro com uma psicoterapeuta permitiu a abertura e o prosseguimento do desenvolvimento libidinal, na fluidez transferencial, de uma relação em que a homossexualidade primária assumia a forma por meio do controle anal.

Fiquemos na transferência primária oral, e em seu conteúdo na relação terapêutica. Digamos que esta desencadeou em Cybelle uma regressão e o surgimento de suas frustrações orais, em uma história pessoal construída a dois, este "dois que é apenas um", ou a extensão de um. Deste modo, a relação com o objeto (estranho ao Ego) está quase que ausente da relação com a terapeuta grandiosa, predominando na transferência o apego até quase a absorção do outro-eu-mesma (transferência primária). Dizemos quase absorção, já que a diferenciação entre sujeito e objeto não estava elaborada. Assim, os vômitos, ou absorção virtual do objeto, levavam-na a elaborar uma substância inconsistente, fluida, como os vomitados, elementos misturados na relação.

O investimento na transferência faz-se por meio de uma adesão à substância maleável ou à unidade complementar com o terapeuta. Podemos pensar em um primeiro tempo em uma união narcísica, no sentido de objeto transicional, do qual a adolescente não podia se separar. Todo objeto transicional é portador das características orais (uma parte de si mesmo) e anais (é sujo e composto pela agressividade da criança). A adolescente elabora uma relação exaltada com sua terapeuta, projetando seu Ideal do Ego sobre o objeto em espelho. O objeto da 


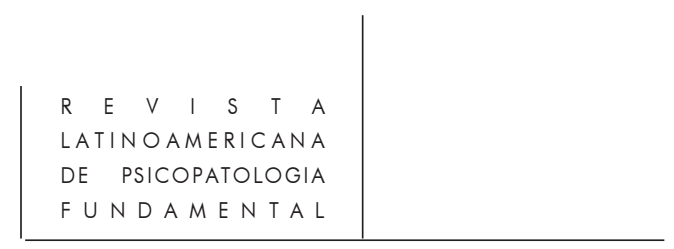

transferência traz todas as características da mãe fálica nutriz. Cybelle isola-se na relação sem uma demanda explícita, com uma passividade receptiva, na espera de satisfação permanente. $\mathrm{O}$ caráter quase não ambivalente na relação de transferência perde sua imutabilidade no momento em que a terapeuta recusa responder as perguntas da adolescente sobre seus sintomas. O silêncio do terapeuta, seu não-saber sintomático eram vividos pela adolescente como a frustração de uma mãe que se revelava menos poderosa do que ela acreditava poder ser.

A reconstrução de uma história libidinal continua seu curso, no momento em que a terapeuta convida a falar, a comprometer-se, a investir, a começar a dar-se, quase na obrigação de reparar, reconstruir os traumas vividos sob um modo oral e anal. Por intermédio desta transferência na oralidade, até mesmo narcísica, a adolescente pôde situar-se como sujeito, amar a si mesma. A terapia continua e o processo de uma maturidade pulsional evolui no plano tópico, dinâmico e econômico.

\section{A analidade estruturante: "Eu guardo tudo para mim"}

A oralidade nunca é pura e, felizmente, as características de uma fixação oral são contrabalançadas pela entrada na analidade. A adolescente desenvolve durante o tratamento sua capacidade de controle, de corte na relação (duas semanas sem vir à sessão/separação), ou seja, uma contra-oralidade ou um contranarcisismo por meio dos elementos pulsionais como o domínio.

O conteúdo da analidade está presente como retenção, as questões do dom, da troca, do domínio e do controle são colocadas na relação de transferência. Esta afirmação - "Eu guardo tudo para mim" - é um esboço de uma "identidade do sujeito Eu". A partir desta oposição, se podemos dizer, a relação com o outro vai se estruturar diferentemente, a saber, o estabelecimento da negação (diferente do "déni" recusa), de uma linha de demarcação entre a adolescente e o outro em que sua retenção anal marca sua autonomia em relação ao seu corpo. Por intermédio da relação transferencial anal, Cybelle pôde reestruturar seu corpo pulsional.

A privação do prazer e do ataque narcísico eram os traços marcantes da relação oral. A adolescente começa a controlar o que está no interior de seu corpo e a libidinização da analidade leva-a a uma autonomia, encontrando prazer por si mesma, com o fechamento da relação de dependência oral, e superando as feridas provocadas por tal dependência. A relação na transferência edifica-se com um objeto separado de si mesmo, com o prazer do domínio e da manipulação do objeto.

Em consequiência do registro primário da transferência, uma grande parte da terapia baseada sobre o holding winnicottiano, esclarecemos por meio de nossa formulação "Você guarda o alimento...", a diferenciação entre pensamento e alimento. 


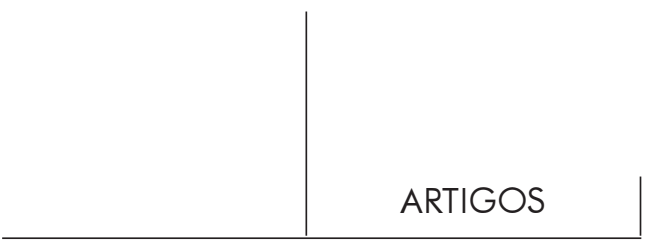

Delimitamos as características da analidade: de um lado, a retenção das fezes, de outro, a distinção entre introduzir no corpo o alimento necessário para viver e o pensamento. Estávamos em uma posição quase maternal de demanda de "aprendizagem dos esfíncteres", demanda que não podia ser formulada no nível oral. No entanto, ela estava centrada sobre a abertura do sistema anal, e sobre uma discriminação entre o objeto anal bom, que deve ser conservado, e o objeto mau, que deve ser rejeitado. Em relação ao pensamento, o fato de guardar para si tudo era um esboço, na relação transferencial de uma história pessoal.

Esta história pessoal carregada de conteúdo anal estava contaminada pela humilhação como ameaça narcísica face ao outro, colocando em perigo o próprio sujeito. A retenção é, então, uma proteção contra a dependência oral e a passividade na relação com o objeto de transferência. O conteúdo desta passividade oral tornase humilhação anal em uma relação com um objeto demasiadamente potente para que ela possa controlar. Em lugar do par antitético, temos a passividade humilhante face ao objeto grandioso.

\section{A reconstrução}

Cybelle começa uma psicoterapia como muitos adolescentes, com elementos inabordáveis. O processo terapêutico vem dar forma ao discurso que parece estar colocado ao lado de uma revelação.

Dizer significa, para a adolescente, uma (re)construção completa de sua história. Reconstrução não somente no nível dos acontecimentos, mas no nível de uma abertura psíquica para o "sentido": encontrar o sentido em sua própria história, encontrar-se.

O conteúdo de tal história "não-dita" era o elemento indispensável à organização psíquica do sujeito. Este "elemento escondido", no fundo de si mesma, talvez lhe permitisse uma articulação, ainda que frágil, entre narcisismo e relação de objeto. Mas este conteúdo implicava a humilhação da submissão total ao protagonista principal do conflito psíquico. O personagem central era a mãe onipotente (à mãe primária). De forma masoquista, o "não-dito" assegura uma identificação primária.

A relação de transferência permitiu um desinvestimento e uma desidealização do objeto onipotente, e por meio dos elementos de origem anal, como a contestação, a crítica, o ataque do objeto grandioso, a objetalização da relação pôde se construir. Apenas neste momento, a adolescente pôde reconstruir sua história, encontrando seu passado. Esta reconstrução só pode ser desenvolvida no tempo terapêutico, tempo flutuante no espaço do tratamento. 


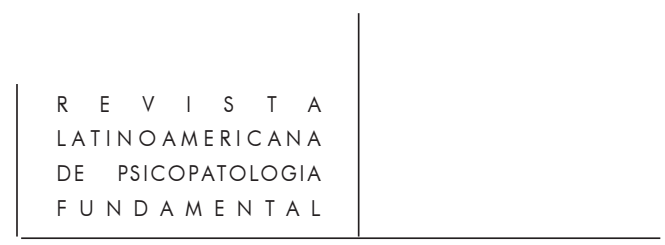

O fim e o começo de uma terapia na adolescência

Chegamos ao fim deste percurso, com um pensamento: o da (re) construção da história adolescente, para conclui-la, voltemos ao começo. Durante a trajetória do nosso discurso e pensamento, citamos S. Freud, indo de 1904, 1905, 1912. Ao final deste percurso, que é apenas o começo, chegamos a 1939.

Neste ano, em seu último escrito, S. Freud (1939) evidencia a necessidade para o sujeito do afastamento dos estímulos sensoriais, para que, no encaminhamento da construção psíquica, o sujeito libere-se do corpo materno investido de sensorialidade, para investir a vida espiritual. Ele passa de um sistema matriarcal para o sistema patriarcal; é o progresso da vida que vai do sentido ao espírito. Não vamos desenvolver este processo que vai da percepção sensorial ao pensamento. Temos uma tese para demonstrar este percurso que vai do investimento infantil do sensorial materno à elaboração do pensamento adolescente, para utilizar o termo de S. Freud, o pensamento baseado na religião do "Pai invisível".

Este processo citado é também um processo no tratamento do adolescente. Nossa atenção, no início do tratamento, estava dirigida para o sensório-visual. A construção arquitetônica transferencial e contratransferencial encontra elementos por meio do sensorial, para chegar a uma elaboração psíquica. É uma trajetória da percepção ao pensamento, do mundo externo para o mundo interno.

A terapia com adolescentes em dificuldade, como Cybelle, implica a posição do terapeuta de ter diante de seus olhos a imago deste adolescente, ou então de ter o olhar de Tirésias para o Édipo-adolescente, ou tornando-se adolescente. Mas esta visão é, às vezes, o fruto do processo do tratamento. Com os adolescentes com risco de perder a imagem (do terapeuta) diante de seus olhos e, conseqüentemente, perder a vida, não estamos em situação ideal. A do analista com o manejo da moldura interna e externa ou a visão de Tirésias é uma aquisição antecipada pelo funcionamento psíquico do adolescente (bem neurótico) e, assim, pela moldura interna e externa do tratamento. Pelo contrário, estamos lá, face a face, com nosso olhar que é fonte de representações. Elas são utilizadas na construção da imago adolescente, por exemplo, quando evocamos um "quadro masoquista".

O tratamento de Cybelle começou pela reunião daquilo que a adolescente deixava "ver" exteriormente, a saber, a imago adolescente em uma relação primária. Depois da visão desviada para o interior mais secundarizado, era quase o fim do tratamento e o princípio do pensamento adolescente. 


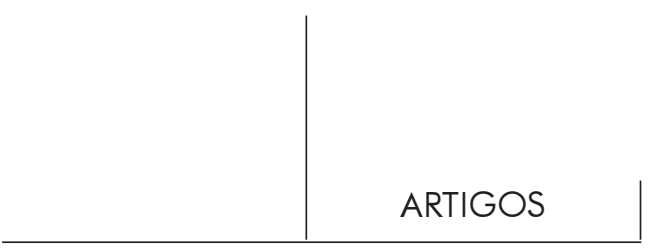

Resumos

El autor propone una reflexión sobre el plañe de la cura de una adolescente anoréxica. A partir del material clínico se sugieren todo a lo largo del articulo preguntas sobre la transferencia y la contratransferencia.

El autor adelanta implícitamente la idea del lugar primordial que pertenece a la transferencia primaria (sensorial) en la cura de los adolescentes. Y su evolución hacia una transferencia más segunda rizada en dirección del pensamiento simbólico del adolescente.

Palabras llave: Psicoanálisis, transferencia, contratransferencia, adolescentes, clinica

L'auteur propose une réflexion sur le cadre de la cure d'une adolescente anorexique. A partir du matériel clinique, quelques questions sont soulevés tout le long de l'article sur le transfert et le contre-transfert. L'auteur avance implicitement l'idée de la place primordiale que le transfert primaire (sensoriel) occupe dans la cure des adolescent: et son evolution vers un transfert plus sécondarisé vers la pensée symbolique adolescente.

Mots clés: Psychanalyse, transfert, contre-transfert, adolescentes, clinic

The author expresses a reflection on the frame of a cure for an anorexic adolescent.

From the clinic material, some questions are raised throughout the article concerning the transfer and counter-transfer.

Implicity the author advances the idea that the primary transfer (sensorial) involves a primordial situation for the adolescents cure. It also demonstrates an evolution of a secondary transfer towards of an adolescent's symbolical thought.

Key words: Psychoanalysis, transfer, counter-transfer, adolescents, clinic

Versão inicial recebida em dezembro de 2000

Versão revisada recebida em agosto de 2001 